\title{
O CONTRADITÓRIO NA APLICAÇÃO EM JUÍZOS PRIMA FACIE DA TESE JURÍDICA FIRMADA NO JULGAMENTO DE CASOS REPETITIVOS
}

\author{
THE ADVERSARIAL PRINCIPLE IN PRIMA FACIE JUDGMENTS OF THE LEGAL \\ THESIS FIRMED IN THE TRIAL OF REPETITIVE CASES
}

Juliana Provedel Cardoso ${ }^{1}$

\section{RESUMO}

O presente artigo tem como escopo a análise do contraditório efetivo conceituado a partir do Estado Democrático Constitucional de Direito e da estrutura cooperativa do processo. Nesse sentido, é feita uma análise do modelo de casos repetitivos, com especial relevância para o Código de Processo Civil de 2015, colocados em evidência a improcedência liminar do pedido, os recursos extraordinário e especial repetitivos, e o incidente de resolução de demandas repetitivas. Fixadas as premissas, é feita ainda uma análise do contraditório na aplicação em juízos prima facie da tese jurídica firmada no julgamento de casos repetitivos, na perspectiva da motivação da decisão judicial (discurso do caso) e da ordem jurídica (discurso do precedente).

Palavras-chave: Princípio do contraditório, Código de processo civil de 2015, Modelo de casos repetitivos, Decisão judicial

\begin{abstract}
The present articles objective is to analyse the highly effective adversarial principle from the Constitutional Democratic State of Law and the cooperative process structure. In this sense, an analysis of the repetitive cases model is made with special relevance to the Civil Procedure Codice 2015, put in evidence the preliminary injunction, the repetitive appeals and the resolution incident repetitive demands. With the establishment of the premises, an analysis of the adversarial principle is made on prima facie judgments of the legal thesis firmed in the trial of repetitive cases, in view of the motivation of the court decision (speech of the case) and law (speech of the precedents).
\end{abstract}

Keywords: Adversarial principle, Civil procedure codice 2015, Repetitive case model, Court decision

\footnotetext{
${ }^{1}$ Mestranda em Direito Processual pela Universidade Federal do Espírito Santo - UFES, Espírito Santo, (Brasil). Email: julianaprovedel@gmail.com
} 


\section{INTRODUÇÃO}

A temática do princípio do contraditório guarda especial relevância para a aplicação em juízos prima facie da tese jurídica firmada no julgamento de casos repetitivos, sobretudo em razão das novidades do Código de Processo Civil de 2015, sancionado em março do presente ano.

Não obstante a consabida definição de contraditório como o direito de tomar ciência dos atos processuais e de se manifestar, a nova concepção desse princípio, iniciada a partir da Constituição Federal de 1988, decorrente do Estado Democrático Constitucional de Direito e da estrutura cooperativa do processo, se assumirá marcadamente com o Código de Processo Civil de 2015, como norma fundamental processual, consagrada pelos arts. $7^{\circ}, 9^{\circ}$ e 10 . Assim, a nova normativa processual somente considerará como efetivo contraditório o ato que se revelar mediante a paridade de tratamento entre as partes (art. $7^{\circ}$ ), previamente ofertado, salvo nas hipóteses legais $\left(9^{\circ}\right)$ e que não resultar para as partes uma decisão-surpresa (art. 10).

Nesse sentido, o tema possui relevância concernente à aplicação do Código de Processo Civil de 2015, sobretudo quanto à aplicação em juízos prima facie da tese jurídica firmada no julgamento de casos repetitivos, na perspectiva da motivação da decisão judicial (discurso do caso) e da ordem jurídica (discurso do precedente).

Portanto, a presente análise se dará pelo método dedutivo, com início na apresentação do princípio do contraditório, considerada a sua evolução no mundo jurídico e na perspectiva do processo democrático. Posteriormente, será apresentado o modelo de casos repetitivos do Código de Processo Civil de 2015, com destaque para a improcedência liminar do pedido, os recursos extraordinário e especiais repetitivos e o incidente de resolução de demandas repetitivas. Por fim, será analisada a aplicação do contraditório para o modelo de casos repetitivos, na perspectiva do discurso do caso e do discurso do precedente, quando a aplicação da tese jurídica se der mediante um juízo prima facie (liminarmente). 


\section{O PRINCÍPIO DO CONTRADITÓRIO EM SUA DUPLA DESTINAÇÃO E A GARANTIA DA NÃO SURPRESA}

O principio constitucional do contraditório, e seu desdobramento na garantia do direito de defesa, previsto no artigo $5^{\circ}$, inciso LV, da Constituição Federal de 1988, garante aos litigantes, em todo e qualquer processo, judicial ou administrativo, a participação ativa e contraditória dos sujeitos processuais e a produção da ampla defesa, em franca participação colaborativa com o juiz (CRUZ E TUCCI, 2015, p. 2).

A afirmação de que o contraditório consiste apenas em abertura dos atos processuais às partes, desconsiderada a participação do juiz, está ultrapassada e não encontra mais espaço no atual Estado Democrático Constitucional de Direito (ZANETI JR., 2014, p. 179), construído a partir da Constituição de 1988 que, por sua vez, sedimentou e fortaleceu os princípios fundamentais do processo, a exemplo do contraditório. Por isso, como bem enuncia Hermes Zaneti Jr (2014, p. 179), é na garantia do contraditório que "se irá apoiar a noção de processo democrático, o procedimento em contraditório, que tem na sua matriz substancial a „máxima da cooperação" (Kooperationsmaxima)".

A "máxima da cooperação" (Kooperationsmaxima), assim denominada por Carlos Alberto Alvaro de Oliveira (2015, p. 10), decorre da reformulação da ideia de Franz Klein que, ao realizar uma reforma processual na Áustria, no final do século XIX, proclamou por maior eficiência na aplicação e na realização do direito, impondo ao juiz uma participação mais intensa no processo, como forma de equilibrar as partes e as colocar em igualdade material e formal, entendendo-se o processo como um ambiente de bem estar coletivo (OLIVEIRA, 2015, p. 4).

Carlos Alberto Alvaro de Oliveira (2015, p. 8), com vistas na atual democracia participativa brasileira, afirma que o contraditório revela-se como um princípio essencial que se encontra na base do diálogo judicial e da cooperação, de forma que a "sentença final só pode resultar do trabalho conjunto de todos os sujeitos do processo".

Diz ainda o italiano Vittorio Denti (1989, p. 104-105) que o contraditório, ao passo em que se constitui uma garantia subjetiva para as partes, ainda representa uma garantia objetiva, como um requisito posto para o interesse público à correta administração da justiça. Luigi Paolo Comoglio (2002, p. 748-749) complementa que o contraditório paritário entre os 
litigantes é também uma garantia mínima para que um processo seja considerado um processo justo.

Com efeito, a garantia do contraditório desponta na lição de Cândido Rangel Dinamarco (2001, p. 125) em dupla destinação: “direitos das partes e deveres do juiz”, eis que os litigantes têm o direito de participar do processo, enquanto que o juiz deve propiciar-lhes esses meios, bem como atuar em contraditório durante todo o julgamento. Assim, Antonio do Passo Cabral (2005, p. 449) afirma o princípio do contraditório como um dever de debate e direito de influência.

No mesmo sentido, Daniel Mitidiero (2009, p. 135) complementa que não basta "outorgar direito a influir na construção da decisão, se não se prevê um correlato dever de debate acometido ao órgão jurisdicional".

Bem afirma Piero Calamandrei (1996, p. 334) que o processo é dotado de caráter dialético e, por isso, o processo é decorrente da lei e se desenvolve como uma série de ações e reações sobre as quais cada um dos sujeitos processuais provoca, de acordo com sua atividade, um movimento nos outros sujeitos e espera, dessa forma, um novo impulso para fazê-lo se movimentar novamente.

O processo, portanto, deve ser aberto ao diálogo, orientado pelo método dialético, com o objetivo de favorecer a formação de juízos mais ponderados em ampla colaboração das partes e do órgão judicial, que deverá ocorrer em todos os atos processuais, da pesquisa dos fatos à valorização jurídica da causa (OLIVEIRA, 2015, p. 9).

A cooperação entre as partes e o juízo, no momento da determinação da norma jurídica a ser aplicada e do convencimento do órgão judicial sobre a adequada solução jurídica, se mostra necessária tanto para a devida determinação do conteúdo e do alcance na norma, como também para evitar decisões-surpresa proferidas sobre uma visão jurídica não esperada pelas partes (OLIVEIRA, 2015, p. 12-13).

Somente quando o órgão judicial proporciona o conhecimento prévio da direção do raciocínio jurídico que lastreará a decisão é que estará homenageado o princípio do contraditório, e, por conseguinte, a garantia do processo democrático (OLIVEIRA, 2015, p. 13). 
O Código de Processo Civil de 2015, sancionado em março do presente ano, adotou expressamente em seu art. $1^{\circ}$ a unidade do ordenamento jurídico ao dispor que o processo civil será ordenado, disciplinado e interpretado de acordo com os valores e as normas fundamentais da Constituição de 1988.

Isso significa dizer que o Código de Processo Civil estará necessariamente conforme o Estado Democrático Constitucional de Direito e que qualquer disposição contrária, ou não correspondente, aos valores e às normas fundamentais constitucionais será suprimida do ordenamento jurídico por inconstitucionalidade.

Mantendo a coerência com o referido art. $1^{\circ}$ e com todas as premissas do processo democrático e da democracia participativa debatidas acima, o Código de Processo Civil de 2015 incorporou ao texto, na qualidade de normas fundamentais processuais, a cooperação de todos os sujeitos do processo (art. $6^{\circ}$ ), a paridade de tratamento (art. $7^{\circ}$ ) e o contraditório efetivo (arts. $7^{\circ}, 9^{\circ}$ e 10$)$.

$\mathrm{O}$ art. $6^{\circ}$ dispõe que "Todos os sujeitos do processo devem cooperar entre si para que se obtenha, em tempo razoável, decisão de mérito justa e efetiva”. A simples leitura do dispositivo sedimenta a participação de todos os sujeitos do processo, partes e órgão julgador, em aberta colaboração para os fins do processo democrático, sobre o qual seja reflexo de uma decisão de mérito justa e efetiva, proferida em tempo razoável.

Como não é próprio da unidade do ordenamento jurídico uma norma subsistir sozinha e desvinculada, as normas fundamentais processuais guardam entre si direta e proporcional relação. Deste modo, a cooperação é uma das manifestações do processo democrático, que se realizará "com o exercício dos direitos de ação, de defesa e de manifestação em geral", segundo Paulo Cezar Pinheiro Carneiro (2015).

Como já acima aludido, o contraditório não deve ocorrer apenas em via unilateral, como um monólogo. Enquanto instituição eminentemente dialética, o processo deve se realizar com os requintes do diálogo judicial e da cooperação entre todos os sujeitos processuais, servindo o contraditório em dupla destinação, direito e dever entre as partes e o órgão judicial. Somente assim é que se revelaria o contraditório efetivo. E, por via de consequência, somente realizado o contraditório efetivo é que as partes estarão em posição de igualdade no processo. 
Essa premissa da democracia participativa igualmente estará resguardada no novo Código de Processo Civil, com o art. $7^{\circ}$, ao prescrever: "É assegurada às partes paridade de tratamento em relação ao exercício de direitos e faculdades processuais, aos meios de defesa, aos ônus, aos deveres e à aplicação de sanções processuais, competindo ao juiz zelar pelo efetivo contraditório".

Como forma de assegurar a paridade de tratamento, conferir-se-á às partes a igualdade de oportunidades no processo, competindo ao juiz a garantia de que, no momento em que as partes deduzirem pretensões em juízo ou se manifestarem, será assegurado o contraditório efetivo, sem desvantagens para a parte interessada e para o ex adverso.

No que toca o contraditório efetivo, o novo Código de Processo Civil cuidou de conferir-lhe disposição consoante às premissas doutrinárias apresentadas acima e que há anos vêm se desenvolvendo: o contraditório não apenas como garantia de ciência dos atos do processo e possibilidade de manifestação, mas também como o direito de influenciar na decisão judicial, em plena participação dos sujeitos do processo, sendo devidamente vedado que o órgão julgador profira decisões-surpresa.

Apresentam-se, para tanto, os artigos $9^{\circ}$ e 10:

Art. $9^{O}$ Não se proferirá decisão contra uma das partes sem que ela seja previamente ouvida.

Parágrafo único. O disposto no caput não se aplica: I - à tutela provisória de urgência;

II - às hipóteses de tutela da evidência previstas no art. 311, incisos II e III; III - à decisão prevista no art. 701.

Art. 10. O juiz não pode decidir, em grau algum de jurisdição, com base em fundamento a respeito do qual não se tenha dado às partes oportunidade de se manifestar, ainda que se trate de matéria sobre a qual deva decidir de ofício.

$\mathrm{O}$ art. $9^{\circ}$ impõe como regra o contraditório prévio no processo civil. Por isso, veda ao órgão julgador proferir decisão sem que as partes tenham sido previamente ouvidas, resguardada a ressalva do parágrafo único, incisos I a III, para situações excepcionais em que o contraditório será postergado com a finalidade de preservação de outros direitos (acesso à justiça e utilidade do processo), mas nunca será eliminado. 
Como bem ressaltam Luiz Guilherme Marinoni, Sergio Cruz Arenhart e Daniel Mitidiero (2014) nos comentários ao novo Código de Processo Civil, somente é permitido que o contraditório seja diferido nas hipóteses excepcionais do parágrafo único do art. $9^{\circ}$ por tratarem-se de decisões provisórias. Assim, somente porque são decisões provisórias, isto é, que poderão ser modificadas no decorrer do procedimento é que se admite a exceção ao contraditório prévio, por não invadir o "núcleo duro do direito ao contraditório" (MARINONI; ARENHART; MITIDIERO, 2014).

Por sua vez, o art. 10, que também trata do princípio do contraditório, inovou e incorporou ao texto legal o direito das partes se manifestarem sobre qualquer questão de direito ou de fato no processo, ainda que se trate de matéria apreciável de ofício pelo juiz, sendo-lhe vedado proferir decisão-surpresa.

Com efeito, passa a ser norma fundamental processual o dever de o juiz oportunizar as partes a se manifestarem previamente à decisão judicial, em qualquer grau de jurisdição, não sendo admissível ainda que o órgão julgador decida de modo sobre o qual as partes não detinham nenhuma expectativa para aquele resultado.

Luiz Guilherme Marinoni, Sergio Cruz Arenhart e Daniel Mitidiero (2014) destacam, nesse sentido, que "é absolutamente indispensável tenham as partes a possibilidade de pronunciar-se sobre tudo que pode servir de ponto de apoio para a decisão da causa, inclusive quanto àquelas questões que o juiz pode apreciar de ofício".

Entre o início e o fim do processo, é devido às partes um iter processual esperado, sendo obrigatória a participação das partes em todos os atos do processo, e especialmente quando o juiz invocar norma legal que implicará em encurtamento do caminho processual (devido processo legal) e/ou aplicar tese jurídica diversa daquela pretendida pelo autor ou contestada pelo réu (segurança jurídica).

Por tanto, o contraditório somente se efetivará, se viabilizado às partes a ciência dos atos processuais, a abertura para manifestações, o direito de influenciar na decisão e a vedação à decisão-surpresa.

Uma vez não observados os arts. $9^{\circ}$ e 10 , estarão gravemente lesadas as normas fundamentais processuais e, por unidade do ordenamento jurídico, também estará violada 
norma fundamental constitucional do art. $5^{\circ}, \mathrm{LV}$ da Constituição de 1988 , por força do art. $1^{\circ}$ do novo Código de Processo Civil.

Por isso, a consequência da inobservância dos dispositivos encampados pelos arts. $9^{\circ}$ e 10 por certo é a nulidade da decisão, eis que contrária à norma fundamental do novo Código de Processo Civil e da Constituição Federal de 1988.

\section{O MODELO DE CASOS REPETITIVOS NO CÓDIGO DE PROCESSO CIVIL DE} 2015

Notadamente ao final do século XX e início do século XXI, o desenvolvimento da sociedade de consumo e a ampliação do acesso à justiça, garantida pela Constituição Federal de 1988, gerou um aumento acelerado de demandas judiciais, sobretudo daquelas decorrentes do mercado de consumo, geralmente fundadas em teses repetitivas, sobrecarregando o fluxo no Judiciário e atravancando a solução das lides processuais.

Esse fenômeno, conhecido como litigiosidade de massa, foi tutelado sob a ótica do vigente Código de Processo Civil de 1973, que, a princípio, não contemplava instrumentos processuais para a tutela dessas demandas fundadas em teses jurídicas idênticas.

Somente a partir da Emenda Constitucional n 45/2004, responsável pela concepção constitucional do princípio da duração razoável do processo (art. $5^{\circ}$, inciso LIV, CF/88), é que o desenvolvimento das demandas repetitivas se deu acentuadamente no direito processual civil, com a criação de institutos processuais pretensos a atenuar a morosidade do Judiciário, com destaque para o julgamento prima facie e para os recursos extraordinário e especial repetitivos $^{2}$.

\footnotetext{
${ }^{2}$ Não negamos a existência dos outros institutos processuais capazes de conferir tutela aos litígios repetitivos, mas somente alguns serão colocados em evidência na oportunidade do presente artigo. Nesse sentido, tambpem de acordo com Leonardo José Carneiro da Cunha, ao alertar para o agigantamento na quantidade de litígios repetitivos e para a ineficácia dos instrumentos tradicionais do processo capazes de lidar com essas demandas, afirma que: "Para essas causas repetitivas, é preciso que se conceba um regime processual próprio, com a dogmática específica, que se destine a dar-lhes solução prioritária, racional e uniforme". E reconhece que já existe no ordenamento jurídico brasileiro um regime processual próprio para as causas repetitivas, sistematizado consolidado pelos seguintes institutos: suspensão de segurança para várias liminares em casos repetitivos (art. $4^{\circ}$, $\S 8^{\circ}$, da Lei $8.437 / 1992$; art. 15 , $\S 5^{\circ}$, da Lei 12.016/2009), incidente de uniformização de jurisprudência, afetação de julgamento a órgão indicado pelo regimento interno (art. 555, $\S 1^{\circ}$, do CPC/1973), pedido de uniformização da
} 
Apesar desse avanço no tratamento das demandas de massa, a morosidade processual e a falta de eficácia na solução dos litígios repetitivos continuam sendo um grande entrave à prestação jurisdicional satisfatória.

Sobre essa perspectiva, foi sancionado em março de 2015 o novo Código de Processo Civil, criado por uma comissão de juristas, instituída através do Ato no 379 de 2009, com a seguinte proposta de criação:

[...] no sentido de garantir um novo Código de Processo Civil que privilegie a simplicidade da linguagem e da ação processual, a celeridade do processo e a efetividade do resultado da ação, além do estímulo à inovação e à modernização de procedimentos, garantindo o respeito ao devido processo legal. (BRASIL. Senado Federal. Ato nº 379, 2009).

Assim, a Exposição de Motivos (BRASIL, 2010) da comissão de juristas que segue a apresentação do novo Código de Processo Civil é transparente em seu objetivo de obter um grau mais intenso de funcionalidade e eficiência das normais processuais, além de proporcionar a simplificação do sistema. E ainda consolida: "o novo Código de Processo Civil tem o potencial de gerar um processo mais célere, mais justo, porque mais rente às necessidades sociais e muito menos complexo" (BRASIL, Exposição de Motivos da comissão de juristas, 2010) como forma de permitir ao juiz centrar sua atenção mais intensamente ao mérito da causa.

Nesse sentido, inspirado pela necessidade social de um processo mais simples, célere e eficiente, é que o novo Código de Processo Civil renova e propõe novos institutos de resolução de litígios repetitivos.

O julgamento prima facie, atualmente previsto no art. 285-A, do CPC/1973, autoriza o julgamento do mérito antes mesmo da citação do réu, proferindo uma sentença de total improcedência, quando a matéria for unicamente de direito e no mesmo juízo já houve sido proferida sentença em outros casos idênticos.

interpretação da Lei federal no âmbito dos Juizados Especiais Cíveis Federais, julgamento imediato de improcedência (art. 285-A do CPC/1973), súmula vinculante e julgamento por amostragem dos recursos extraordinário e especial (art. 543-B e 543-D do CPC/1973) (CUNHA, 2010, p. 143). 
Com o novo CPC, o instituto corresponderá ao art. 332, capítulo III, " $D a$ improcedência liminar do pedido", e virá com nova versão, ainda mais ampla do que o conceito atual, mas manterá a mesma essência, ou seja, um julgamento liminar de total improcedência, antes da citação do réu.

Os recursos extraordinário e especial repetitivos, também postos em destaque logo acima, igualmente virão renovados pelo CPC/2015. Os atuais art. 543-B e 543-C, do CPC/1973 dispõem respectivamente sobre os recursos extraordinário e especial repetitivos, que permitem um julgamento por amostragem perante o STF (recurso extraordinário) ou o STJ (recurso especial) de recursos repetitivos, isto é, que versam sobre a mesma questão jurídica. O CPC/2015 manterá a mesma técnica de julgamento para os casos de recursos repetitivos, com alguns importantes acréscimos a partir do art. 1.036 até o art. 1.041, subseção II, "Do julgamento dos recursos extraordinário e especial repetitivos", alguns dos quais serão abordados mais especificamente adiante nesse artigo.

Grande novidade do CPC/2015 é o art. art. 976 a 987, capítulo VIII, “Do incidente de resolução de demandas repetitivas", que não encontra correspondência com o atual Código de Processo Civil de 1973, e que, inspirado no modelo alemão (Musterverfahren) (CABRAL, 2007, p. 128), prevê um julgamento em bloco e em primeiro grau de jurisdição para processos que versem sobre a mesma tese jurídica, derivados da litigiosidade de massa, nas hipóteses em que simultaneamente houver efetiva repetição de processos que contenham controvérsia sobre a mesma questão unicamente de direito (inciso I) e ofereçam risco de ofensa à isonomia e à segurança jurídica (inciso II).

Com o novo paradigma do sistema de precedentes brasileiro proposto pelo CPC/2015, o novo Código considerou como um modelo de casos repetitivos, nos termos do art. 928, a decisão judicial proferida em incidente de resolução de demandas repetitivas (inciso I) e em recursos especial e extraordinário repetitivos (inciso II).

Muito embora o novo Código de Processo Civil não faça previsão expressa no art. 928 para outras hipóteses de casos repetitivos pulverizados na nova normativa processual, não acreditamos que a interpretação literal desse dispositivo seja a melhor para a sistematização e uniformidade do ordenamento jurídico e, principalmente, das normas processuais. 
Por isso, a improcedência liminar do pedido será considerada como uma espécie do gênero de regime processual próprio dos casos repetitivos, juntamente com o incidente de resolução de demandas repetitivas e os recursos extraordinário e especial repetitivos.

Nesse sentido, a aplicação desses institutos de casos repetitivos resulta em uma decisão judicial, sobre a qual o Poder Judiciário deverá se preocupar não apenas para aplicação do caso concreto no julgamento da causa, como também para os efeitos futuros e repercussões sociais dessas decisões, analise que será feita a seguir.

\section{O PRINCÍPIO DO CONTRADITÓRIO E OS DOIS DISCURSOS A PARTIR DA DECISÃO JUDICIAL EM CASOS REPETITIVOS}

A decisão judicial, como bem afirma Daniel Mitidiero (2012, p. 62), desde que fundamentada e enquanto instrumento de reconstrução da ordem jurídica, é alicerce elementar para que a doutrina realize um duplo discurso: "um discurso voltado para o caso concreto e um discurso voltado para a ordem jurídica”.

O primeiro discurso, voltado para o caso concreto, implica no dever de motivação das decisões judiciais e constitui direito fundamental da parte e "núcleo duro do direito ao processo justo" (MITIDIERO, 2012, p. 62), nos termos do art. 5, LIV, e art. 93, IX, da $\mathrm{CF} / 1988$.

Já o segundo discurso, voltado para a ordem jurídica e para as repercussões sociais, se concretiza para conferir unidade do direito e, assim, garantir a segurança jurídica, a igualdade e a coerência normativa (MITIDIERO, 2012, p. 62).

Assim, sob a perspectiva do Estado Democrático Constitucional de Direito (ZANETI JR., 2014, p. 179), a fundamentação e o precedente são dois discursos jurídicos distintos, com destinações e efeitos jurídicos igualmente diferentes. Diante disso, a aplicação do princípio do contraditório, conforme já explicado (item 1), é inerente à decisão judicial e ao atual processo democrático, derivado da democracia participativa. 


\subsection{O PRINCÍPIO DO CONTRADITÓRIO PARA JUÍzOS PRIMA FACIE DO DISCURSO DO CASO}

A Constituição Federal de 1988 estabelece que "todos os julgamentos dos órgãos do Poder Judiciário serão públicos, e fundamentadas todas as decisões, sob pena de nulidade" (art. 93, IX, CF/1988), assim denominado como o dever de motivação das decisões judiciais. A fundamentação das decisões judiciais, inerente ao Estado Democrático Constitucional de Direito, é pressuposto basilar do próprio exercício do direito ao contraditório, uma vez que as partes, somente diante da demonstração do convencimento do juiz e do raciocínio cognitivo da tese jurídica consolidada, é que poderão ter ciência efetiva dos atos e se insurgir em juízo para manifestação em sentido amplo.

O novo Código de Processo Civil, nesse sentido, reforçou o dever constitucional de fundamentação das decisões, que já defendido pelo Código de Processo Civil de 1973 (art. 458, inciso II, e art. 165), virá com toda a força, principalmente através do art. 489 , $\S 1^{\circ}$ e do art. $1.013, \S 3^{\circ}$, inciso IV, que além de fazer exigência expressa ao que se considerará por decisão judicial fundamentada, seja qual for a sua natureza (interlocutória, sentença ou acórdão), ainda prescreve que o efeito da falta de fundamentação é a nulidade da sentença, apreciada por tribunal em sede de apelação.

Da motivação das decisões judiciais surge um problema muito importante, que é a extensão do dever de motivação e que, segundo Daniel Mitidiero, deve ser resolvido a luz do contraditório (2012, p. 63). Assim porque, a motivação da decisão será o último momento para o exercício do contraditório.

Na visão ultrapassada de contraditório como algo referente tão somente às partes, o dever de motivação seria satisfeito pelo órgão judicial apenas com a demonstração de quais razões fundaram a decisão.

A nova visão do direito ao contraditório, em compasso com o Estado Democrático Constitucional de Direito, promove o direito de influir no julgamento, e, em contrapartida, se apresenta também para o órgão judicial como um dever de debate, aliado à estrutura de cooperação no processo. 
Para o discurso do caso (motivação das decisões judiciais) mediante a aplicação da tese jurídica firmada no julgamento de casos repetitivos, especialmente para aqueles destacados no presente estudo (improcedência liminar do pedido, incidente de resolução de demandas repetitivas e recursos repetitivos), para que seja respeitado o contraditório, norma constitucional e fundamental processual, é preciso que se faça uma interpretação acurada do novo Código de Processo Civil.

Com efeito, para o instituto da improcedência liminar do pedido, o art. 332, incisos II e III, do CPC/2015, autoriza que o juiz julgue liminarmente improcedente, independentemente da citação do réu, o pedido que contrariar acórdão proferido pelo Supremo Tribunal Federal ou pelo Superior Tribunal de Justiça em julgamento de recursos repetitivos (inciso II), ou ainda entendimento firmado em incidente de resolução de dema ndas repetitivas (inciso III - não analisado nesse artigo o incidente de assunção de competência).

Note-se que dentre as hipóteses autorizativas para aplicação da improcedência liminar do pedido estão o incidente de resolução de demandas repetitivas e os recursos repetitivos. Isto é, os casos repetitivos (art. 928, NCPC) são objeto de julgamento liminar do pedido.

Em outras palavras, ainda com mais ênfase, a tese jurídica firmada no julgamento de casos repetitivos será fundamento para julgamento liminar de improcedência do pedido do autor, sem que o réu sequer seja citado.

Nesse caso, o dever de motivação da decisão e a extensão dos efeitos da decisão devem ser tomados com tamanha seriedade, sendo a aplicação do contraditório pressuposto inarredável para o discurso do caso, oportunidade em que necessariamente será viabilizado às partes o direito de influir na decisão judicial, em contrapartida ao dever de debate, de consulta e de diálogo do órgão judicial.

Nessa lógica, a tese jurídica firmada no julgamento do incidente de resolução de demandas repetitivas, conforme o art. 985, inciso I, do novo Código de Processo Civil, será aplicada "a todos os processos individuais ou coletivos que versem sobre idêntica questão de direito e que tramitem na área de jurisdição do respectivo tribunal, inclusive àqueles que tramitem nos juizados especiais do respectivo Estado ou região". Igualmente para o incidente de resolução de demandas repetitivas, o contraditório deverá ser aplicado para o discurso do caso, ou seja, no momento da aplicação da tese jurídica. 
Na sequência, o novo Código de Processo Civil disciplinou para o julgamento dos recursos extraordinário e especial repetitivos o contraditório para o discurso do caso, notadamente quanto ao art. 1.037, $\S \S 8^{\circ}$ e $9^{\circ}$. Assim, dispõe o $\mathrm{CPC} / 2015$ que as partes deverão ser intimadas da decisão de suspensão de seu processo, quando determinada a suspensão do processamento dos processos pendentes para julgamento do caso paradigma $\left(\S 8^{\circ}\right)$.

Deste modo, uma vez selecionado o processo paradigma e verificados os processos que serão sobrestados, deve o órgão julgador intimar as partes da decisão que determinar a suspensão para que, previamente à suspensão, possam as partes demonstrar a distinção entre a questão a ser decidida no processo e aquela a ser julgada no recurso extraordinário ou especial afetado, e, assim, requerer o prosseguimento do seu processo $\left(\S 9^{\circ}\right)$.

Tão necessário o contraditório para o discurso do caso, que deverá ser exercido tão logo decida o órgão julgador pela tese jurídica, ainda que se trate de decisão que determine a suspensão do recurso repetitivo. Caberá ao órgão julgador, em vista da estrutura cooperativa de processo, intimar as partes, nos termos do art. $1.037, \S \S 8^{\circ}$ e $9^{\circ}$, para demonstrar a motivação do seu convencimento em suspender os recursos repetitivos, previamente à suspensão, para que, nessa oportunidade, possam as partes, se quiserem, demonstrar a distinção com o caso paradigma e requerer o prosseguimento do seu processo.

O contraditório, se exercido apenas em momento postergado, já quando suspensos os recursos repetitivos, resulta em prejuízo grave para a parte que tentará desfazer algo que já foi feito, convencer de forma oposta ao que já se firmou o órgão julgador. Isso implica em uma manobra extremamente penosa para as partes de tal forma que, nesse caso, o contraditório postergado representaria um esvaziamento do exercício do contraditório. Essa interpretação nega o Estado Democrático Constitucional de Direito e o dever de motivação, sob a ótica do processo democrático.

Jordi Nieva Fenoll (2007, p. 59) ainda diz que em um procedimento de juízo prima facie para casos em que a celeridade é uma necessidade imposta pelo legislador, a motivação da decisão judicial é exigência elementar, que não poderá ser sequer mitigada ou reduzida.

A aplicação do contraditório no discurso do caso, portanto, deverá ocorrer quando da aplicação da tese jurídica, especialmente para os institutos em destaque, com a participação 
ativa e contraditória de todos os sujeitos do processo, considerado o contraditório em sua dupla destinação de direitos e deveres e a estrutura cooperativa do processo.

\subsection{O PRINCÍPIO DO CONTRADITÓRIO PARA JUÍzOS PRIMA FACIE DO DISCURSO DO PRECEDENTE}

A decisão judicial, por outro lado, abre a oportunidade para o discurso do precedente, voltado para a ordem jurídica e para as repercussões sociais. Esse discurso se destina a conferir uma unidade do direito, a partir da decisão judicial, como forma de manter e desenvolver o sistema jurídico preservado pela segurança jurídica, pela igualdade e pela coerência normativa (MITIDIERO, 2012, p. 62).

Exatamente porque o discurso do precedente se desenvolve institucionalmente e se destina para a sociedade em geral, é que possui "vocação necessariamente erga omnes", como bem afirma Daniel Mitidiero (2012, p. 69).

A referência ao discurso do precedente, de forma diversa ao discurso do caso (fundamentação da decisão judicial), deverá ocorrer, para que não se esbarre na limitação da tradição romano-canônica da codificação civil, diante da abertura constitucional ao stare decisis (ZANETI JR., 2014, p. 25) pela Constituição Federal de 1988, por meio da Emenda Constitucional $n^{\circ} 45 / 2005$, que inaugurou e inspirou a criação de institutos processuais que promovessem a previsibilidade das decisões dos tribunais pátrios (v.g. julgamento prima facie, recursos repetitivos, entre outros).

O novo Código de Processo Civil, elaborado após a Constituição de 1988, incorporou de forma mitigada os valores da tradição jurídica de common law, e ao que se detém principalmente dos arts. 926, 927, 928, 489, criou um sistema de precedentes brasileiro, manifestamente destinado à estabilidade das decisões judiciais e à normatização do precedente de caráter vinculante.

Dessa maneira, o discurso do precedente, igualmente para o discurso do caso, deverá ser orientado pelo contraditório prévio, especialmente para os casos de aplicação em juízos prima facie (liminar) da tese jurídica firmada no precedente no julgamento de casos repetitivos, objeto do presente artigo. 
O respeito ao contraditório prévio nessas hipóteses de juízos prima facie revela uma preocupação ainda maior, porque o resultado da violação a essa garantia implica em lesão grave a outros princípios constitucionais, como o acesso à justiça, a igualdade e o devido processo legal (NERY JR., 2010, p. 86-87).

Por isso, em uma análise da improcedência liminar do pedido, o acerto na interpretação sistemática é elementar para o tema. O art. 332, do CPC/2015, autoriza que o juiz, independentemente da citação do réu, julgue liminarmente o pedido do autor que contrariar: enunciado de súmula do STF ou do STJ (inciso I), acórdão proferido pelo STF ou pelo STJ em julgamento de recursos repetitivos (inciso II), entendimento firmado em incidente de resolução de demandas repetitivas ou de assunção de competência (inciso III), enunciado de súmula de tribunal de justiça sobre direito local (inciso IV) e se verificar desde logo a ocorrência de decadência ou de prescrição $\left(\$ 1^{\circ}\right)$.

Em uma interpretação sistemática com o novo Código de Processo Civil, podemos perceber que as hipóteses dos incisos I ao III do art. 332 se equivalem àquelas em que o CPC/2015 estabeleceu em seu art. 927, incisos III e IV como precedentes vinculantes. O código processual passará a considerar como precedentes vinculantes, que deverão ser observados por juízes e tribunais, os acórdãos em incidente de assunção de incompetência ou de resolução de demandas repetitivas e em julgamento de recursos extraordinário e especial repetitivos (inciso III) e ainda os enunciados das súmulas do STF em matéria constitucional e do STJ em matéria infraconstitucional (inciso IV).

Com efeito, o $\S 1^{\circ}$ do art. 927 (precedentes vinculantes), do CPC/2015 destaca que:

$\S 1^{\mathrm{o}}$ Os juízes e os tribunais observarão o disposto no art. 10 e no art. 489, $\S 1^{\mathrm{O}}$, quando decidirem com fundamento neste artigo.

Assim, a norma processual é clara ao dizer que quando o órgão julgador decidir com fundamento nos precedentes (art. 927), deverá observar o princípio da não surpresa e do contraditório prévio (art. 10), bem como a devida fundamentação da decisão judicial (art. 489, $\left.\S 1^{\circ}\right)$.

Como já demonstrado, as hipóteses de precedentes vinculantes são exatamente as mesmas em que o julgador está autorizado a julgar liminarmente improcedente o pedido do 
autor. Dessa forma, é forçoso que se confie ao instituto da improcedência liminar do pedido (art. 332) as mesmas garantias consagradas para a fundamentação da decisão judicial com base em precedentes.

Dessa forma, não poderá o autor da demanda ser surpreendido por uma decisão liminar de total improcedência, sem que sequer saiba a racionalidade construída por determinado juízo para a aplicação dos precedentes, hipóteses do art. 332, os quais seu pedido contrariou.

O princípio do contraditório, nas palavras de Nicola Picardi (1998, p. 679), representa uma necessidade imanente ao processo. Por isso, só é possível dizer que houve processo quando na sua formação foi respeitado o contraditório, ou seja, foi consentido às partes participarem da esfera de reconhecimento dos pressupostos dos atos processuais, colocando-as, inclusive, em paridade de armas (PICARDI, 1998, p. 678-679).

Assim, compartilhando da doutrina de Antonio Carlos de Araújo Cintra, Ada Pellegrini Grinover e Cândido Rangel Dinamarco (2009, p. 63), “o contraditório não admite exceções”.

Daniel Mitidiero (2009, p. 136) é enfático ao dizer que somente poderá haver pronunciamento jurisdicional em "elementos sobre os quais as partes tenham tido oportunidade de se manifestar", sendo esse o significado de se "evitar a decisão-surpresa no processo". Quando não é observada a vedação à decisão-surpresa, Daniel Mitidiero (2009, p. 137) afirma que há evidente violação à cooperação e ao diálogo no processo, com afronta ao dever judicial de consulta e ao contraditório.

Nesse sentido, importante lição de Carlos Alberto Alvaro de Oliveira (2015, p. 13):

Dentro dessa mesma orientação, a liberdade concedida ao julgador na eleição da norma a aplicar, independentemente de sua invocação pela parte interessada, consubstanciada no brocardo iura novit curia, não dispensa a prévia ouvida das partes sobre os novos rumos a serem imprimidos ao litígio, em homenagem, ainda aqui, ao princípio do contraditório.

Carlos Alberto Alvaro de Oliveira (2015, p. 13) diz decorrer dessa problemática não apenas o interesse das partes, mas também o "próprio interesse público, na medida em que qualquer surpresa, qualquer acontecimento inesperado, só faz diminuir a fé do cidadão na 
administração da justiça”. O autor (OLIVEIRA, 2015, p. 13) ainda é enfático ao expor que essa problemática torna-se uma "autêntica garantia de democratização do processo".

A esse respeito, Daniel Mitidiero (2009, p. 137) igualmente afirma que a exigência à vedação à decisão-surpresa encontra "evidente respaldo no interesse público de chegar-se a uma solução bem amadurecida para o caso levado a juízo".

A garantia da não surpresa, promovida pelo princípio do contraditório deve ser considerada para a improcedência liminar principalmente em benefício do autor. Como bem pontua Marcelo Abelha Rodrigues (2010, p. 74), somente se exercido em favor do autor pelo juiz, é que o contraditório "alcança um estado democrático de direito".

Portanto, deve ser oportunizado ao autor o contraditório prévio para dar-lhe oportunidade de tomar ciência da intenção do magistrado em decidir nos termos do art. 332, do CPC/2015, inclusive quanto ao fundamento de motivação para a decisão judicial, mesmo que independentemente da citação do réu, como pretende o instituto.

Assim, considerada a necessária observação à garantia da vedação à decisão- surpresa, sobretudo diante da improcedência liminar do pedido, em razão da interpretação sistemática sobre o sistema de precedentes e o art. $927, \S 1^{\circ}$, do CPC/2015, bem como diante da estrutura cooperativa do processo democrático, somente se torna possível, sob a ótica da constitucionalidade, a aplicação prima facie da tese jurídica firmada para a aplicação do precedente para os casos repetitivos, se oportunizado o contraditório prévio ao autor.

\section{CONSIDERAÇÕES FINAIS}

Como exposto, o conceito do princípio do contraditório (art. 5º LV, CF/88), desdobrado na garantia do direito de defesa, se fortaleceu no atual Estado Democrático Constitucional de Direito, através do qual passou a ser exigência elementar do processo, garantindo a participação ativa e contraditória dos sujeitos processuais, em ampla cooperação entre as partes e o órgão julgador.

O processo, instituição eminentemente dialética, somente pode adquirir o necessário caráter democrático quando a formação da decisão judicial for resultado de juízos ponderados e 
da participação colaborativa entre as partes e o juiz. Destina-se, portanto, o contraditório como dever de debate e direito de influência sobre a decisão judicial.

O Código de Processo Civil de 2015, elaborado após a Constituição Federal de 1988, incorporou os valores constitucionais da democracia participativa e inaugurou como normas fundamentais processuais a cooperação de todos os sujeitos do processo (art. $6^{\circ}$ ), a paridade de tratamento das partes (art. $7^{\circ}$ ) e o contraditório efetivo (arts. $7^{\circ}, 9^{\circ}$ e 10 ).

Para a nova ordenação processual civil, somente será considerado contraditório efetivo o que proporcionar a igualdade entre as partes, exercido previamente, ressalvadas as hipóteses legais em que será admitido de forma postergada, e, finalmente, quando a decisão judicial tiver por fundamento tese jurídica sobre a qual tiveram as partes previamente oportunidade de se manifestar (vedação à decisão-surpresa).

Assim, em vista da concepção do princípio do contraditório conforme demonstrado, buscou-se analisar o procedimento próprio dos casos repetitivos, especialmente quanto ao julgamento prima facie e os recursos extraordinário e especial repetitivos, desenvolvido a partir da Emenda Constitucional no 45/2004, como forma de conferir celeridade processual e um julgamento mais racionalizado para os tribunais, bem como as modificações dos institutos vigentes e o novo incidente de resolução de demandas repetitivas propostos pelo Código de Processo Civil de 2015.

Não obstante o robustecimento do regime próprio para os casos repetitivos, a partir da EC nº 45/2004 e notadamente do Código de Processo Civil de 2015, a intenção em garantir um ordenamento jurídico mais estável e célere não pode se perpetrar em uma aplicação desatinada dos casos repetitivos de forma automática, tratando-se a decisão judicial como uma atividade mecânica. O processo deve se desenvolver, em regra, a partir do diálogo judicial, da cooperação entre as partes e do contraditório prévio e efetivo.

Nesse sentido, a análise da aplicação prima facie da tese jurídica firmada no julgamento dos casos repetitivos resulta em uma decisão judicial sobre a qual se deva ter, diante da preocupação com o contraditório efetivo, uma abordagem a partir do duplo discurso: um voltado para o caso concreto e outro voltado para a ordem jurídica.

O primeiro discurso, tratado como o discurso do caso, implica no dever de motivação das decisões judiciais, especialmente quanto à sua extensão, que deverá ser realizada a luz do 
contraditório. Assim, para os casos repetitivos, o contraditório prévio deverá ser exercido tão logo se decida por aplicar a tese jurídica para efeitos de casos repetitivos.

Já o segundo discurso, assim considerado como o discurso do precedente, voltado para a ordem jurídica, se destina a conferir uma unidade do direito, a partir da decisão judicial. Por isso, na aplicação prima facie da tese jurídica firmada em casos repetitivos, o contraditório prévio é condição necessária imposta pelo Código de Processo Civil de 2015, a partir da interpretação sistemática dos precedentes e da garantia da vedação à decisão- surpresa (art. 332, incisos I ao III e art. 927, incisos III e IV, e $\S 1^{\circ}$ ), juntamente com a estrutura cooperativa do processo democrático. Quer-se, com isso, evitar que o autor seja surpreendido por uma sentença liminar de total improcedência, completamente imprevisível às suas expectativas.

\section{REFERÊNCIAS BIBLIOGRÁFICAS}

BRASIL. Exposição de Motivos da comissão de juristas do novo Código de Processo Civil. Disponível em: <http://legis.senado.leg.br/mateweb/arquivos/mate-pdf/160823.pdf>. Acesso em: 04 mar. 2015. 24p.

CABRAL, Antonio do Passo. Il principio del contraddittorio come diritto deinfluenza e dovere di dibattito. Rivista di Diritto Processuale, Itália: CEDAM, ano LX (Seconda Serie), n. 2, aprile-giugno, 2005. 632p.

CABRAL, Antonio do Passo. O novo procedimento-modelo (Musterverfahren) alemão: uma alternativa às ações coletivas. Revista de Processo, São Paulo, ano 32, n. 147, p. 123-146, mai. 2007. 390p.

CALAMANDREI, Piero. Instituciones de Derecho Procesal Civil: segun el nuevo codigo. Buenos Aires: El Foro, 1996. v. I. 421p.

CARNEIRO, Paulo Cezar Pinheiro. Capítulo I. Das Normas Fundamentais do Processo Civil. In: WAMBIER, Teresa Arruda Alvim et al. (Org.). Breves Comentários ao novo Código de Processo Civil. São Paulo: RT, 2015. (livro digital). 
CINTRA, Antonio Carlos de Araújo; GRINOVER, Ada Pellegrini; DINAMARCO, Cândido Rangel. Teoria Geral do Processo. 25. ed. São Paulo: Malheiros, 2009. 384p.

COMOGLIO, Luigi Paolo. Il giusto processo civile nella dimensione comparatistica. Rivista di Diritto Processuale, Itália: CEDAM, ano LVII (Seconda Serie), n. 3, luglio-settembre, 2002. 980p.

CRUZ E TUCCI, José Rodgério. Garantia Constitucional do Contraditório no Projeto do CPC. Disponível em: <http://www.iabnacional.org.br/IMG/pdf/doc-3545.pdf >. Acesso em: 03 jul. 2015. 35p.

CUNHA, Leonardo José Carneiro da. O regime processual das causas repetitivas. Revista de Processo, São Paulo, ano 35, n. 179, p. 139-174, jan. 2010. 396p.

DINAMARCO, Cândido Rangel. Fundamentos do Processo Civil Moderno. 4. ed. São Paulo: Malheiros, 2001. Tomo I. 695p.

FENOLL, Jordi Nieva. Enjuiciamiento prima facie. Barcelona: Atelier Libros Juridicos, 2007. 225p.

MARINONI, Luiz Guilherme; ARENHART, Sergio Cruz; MITIDIERO, Daniel. Novo Código de Processo Civil comentado. São Paulo: RT, 2014. (livro digital) MITIDIERO, Daniel. Colaboração no processo civil. São Paulo: RT, 2009.

MITIDIERO, Daniel. Fundamentação e precedente - dois discursos a partir da decisão judicial. Revista de Processo, São Paulo, ano 37, v. 206, p. 61-78, abr. 2012. 523p.

NERY JR., Nelson. Princípios do Processo na Constituição Federal. 10. ed. São Paulo: Revista dos Tribunais, 2010. 416p.

OLIVEIRA, Carlos Alberto Alvaro de. Poderes do juiz e visão cooperativa do processo I. Disponível em: <http://www.abdpc.org.br/abdpc/artigos/Carlos\%20A\%20A\%20de\%20Oliveira\%20(8)\%20formatado.pdf $>$. Acesso em: 03 jul. 2015. 25p.

PICARDI, Nicola. Il principio del contraddittorio. Rivista di Diritto Processuale, Itália: CEDAM, ano LIII (Seconda Serie), n. 3, luglio-settembre 1998. 939p. 
RODRIGUES, Marcelo Abelha. Manual de Direito Processual Civil. 5. ed. São Paulo: Revista dos Tribunais, 2010. 879p. DENTI, Vittorio. La giustizia civile. Bologna: Mulino, 1989. 221p.

ZANETI JR, Hermes. A Constitucionalização do Processo: o modelo constitucional de justiça brasileira e as relações entre processo e constituição. 2. ed. São Paulo: Atlas, 2014. $271 \mathrm{p}$. 